Teller, Christoph, Dennis, Charles. The Effect of Ambient Scent on Consumers' Perception, Emotions and Behaviour - a Critical Review. Journal of Marketing Management, accepted, in print, DOI: 10.1080/0267257X.2011.560719.

\title{
The Effect of Ambient Scent on Consumers' Perception, Emotions and Behaviour - a Critical Review
}

Christoph Teller ${ }^{\mathrm{I}}$, Charles Dennis ${ }^{\mathrm{II}}$

I, [corresponding author] Institute for Retail Studies, University of Stirling; Stirling FK9 4LA; United Kingdom; Tel: ++44 (0) 178646 6454; Fax: ++44 (0) 178646 5290;

Email: christoph.teller@stir.ac.uk;

II, Brunel Business School, Brunel University; Uxbridge, UB8 3PH, United Kingdom; Tel: ++44 (0) 189526 5242; Fax: +44 (0) 189526 9775; Email: charles.dennis@ brunel.ac.uk 


\title{
The Effect of Ambient Scent on Consumers' Perception, Emotions and Behaviour - a Critical Review
}

\begin{abstract}
The effect of olfactory stimuli on consumer behaviour has received little attention in marketing and retailing literature compared to other atmospheric cues. Researchers report ambiguous findings and shortcomings of measurement approaches. Based on a critical literature review, a field experiment in a regional shopping mall investigates the effectiveness of ambient scent. Before-and-after surveys of randomly-selected shoppers in experimental and control groups were conducted and different experimental designs simulated. Those designs not controlling either extraneous variables or attitudinal differences between control and experimental group reveal a positive effect on factors operationalising mall perception and consumers' emotions. The design controlling both sources of bias indicates no impact of ambient scent on the dependent variables. None of the behavioural variables were affected in any case. This paper questions prior findings on the effectiveness of ambient scent in a shopping mall environment and calls for more rigour in investigating the effectiveness of atmospheric stimuli in general.
\end{abstract}

\section{Keywords}

Ambient scent, Atmosphere, Shopping Mall, Experiment, Consumer Behaviour 


\section{The Effect of Ambient Scent on Consumers' Perception, Emotions and Behaviour - a Critical Review}

\section{Introduction}

The phenomenon 'atmosphere' and its impact on consumer behaviour has widely been considered in research over decades (Turley \& Milliman, 2000). Atmosphere can be regarded as a multi-faceted, latent construct which is decomposed into different atmospheric stimuli or cues. These stimuli are proposed to be (1) recognisable by consumers' senses, (2) can lead to an intended reaction and (3) be effectively manipulated by retailers (Kotler, 1973; Turley \& Chebat, 2002). Only few atmospheric related studies have considered the role of ambient scent and its impact on consumer behaviour (Turley \& Milliman, 2000; Chebat \& Michon, 2003).

Nonetheless, the body of literature dealing with the effectiveness of ambient scent can be regarded as fragmented. Some articles investigate the impact of scent in terms of products or brands (Bone \& Jantrania, 1992; Mitchell, Kahn \& Knasko, 1995; Morrin \& Ratneshwar, 2000) and some in terms of products and stores (Spangenberg, Crowley \& Henderson, 1996; Orth \& Bourrain, 2005). Most of the articles focus on the effectiveness of ambient scent in retail store or other store-like environments (Knasko, 1989; Hirsch, 1995; Mattila \& Wirtz, 2001; Gueguen \& Petr, 2006). Increasingly, publications deal with ambient scent in shopping mall settings (Chebat \& Michon, 2003; Michon, Chebat \& Turley, 2005). The measurement approaches and experimental designs to evaluate the relationship between the use of ambient scents and the proposed dependent variables also vary. Differences include the selected test units, the experimental environment, the sample selection procedure, the type of stimulus (ambient scents) etc. Furthermore, the results are ambiguous. A number of papers present insignificant, minor or only indirect effects of ambient scent on attitudinal and in particular 
behavioural variables (e.g. Mattila \& Wirtz, 2001; Chebat \& Michon, 2003; Orth \& Bourrain, 2005; Gueguen \& Petr, 2006).

Consequently, the question of whether 'smell sells' or whether the use of olfactory stimuli results in reactions that are desirable from the point of view of marketing managers cannot yet be answered with a definite 'yes' (Bone \& Ellen, 1999). Some researchers provide quite logical justification for this unsatisfactory state of the art of literature. For example, Gulas and Bloch (1995), Bone and Ellen (1999) and Ward, Davies and Kooijman (2002) identify sets of variables that might moderate or mediate the effect of ambient scent on consumer behaviour yet still remain to be considered by researchers. Moderators and mediators include atmospheric cues such as other olfactory stimuli, individual (e.g. demographic or psychographic) characteristics of consumers, congruency of scent, past experience, physiological predispositions, scent preference or perception of scent. Notwithstanding, only few studies include any of these moderators and confirm their relevance (e.g. Chebat \& Michon, 2003; Michon et al., 2005; Orth \& Bourrain, 2005).

Due to the ambiguous findings on the effectiveness of ambient scent in literature, this paper focuses on the following research question: What consumer reactions can be identified when ambient scent is used in a retail environment? Besides addressing the research question the aims of this paper are (1) to critically evaluate existing results and applied methodology in marketing and retail related research on the effectiveness of ambient scent in a shopping environment; (2) to empirically test the effect of ambient scent by applying different experimental approaches; and (3) discuss the current state of the art of olfaction research in marketing and retailing with respect to the identified shortcomings in literature. Thus the contribution of this research is to question both the validity of existing findings on and the 
appropriateness of applied experimental approaches to measure the effectiveness of ambient scent - with an explicit focus on marketing and retail research.

The realm of the paper is as follows: based on this introduction we discuss the findings from literature in terms of the effects of ambient scent on shopping behaviour and the different research designs applied. A conceptual framework is developed and consequently used to frame hypotheses and operationalise variables. Next, the research design and the results of an empirical study are presented, then discussed with respect to prior findings. The paper concludes with a short summary and an outlook for further research.

\section{Literature review}

In line with the research question, this literature review focuses mainly on those publications dealing with the effect of ambient scent in a marketing and retail related context. Turley and Milliman's (2000) synthesis of publications on atmospherics effects indicates that ambient scent had not received enough attention compared to other atmospheric cues. Only three out of 60 empirical studies had been identified that focused on ambient scent as an independent variable. More than a decade later the situation is little changed. We identified just eight more journal publications in refereed journals that investigate the effect of ambient scent on consumer behaviour related reactions (see Table 1). In all of these articles concerning ambient scent, (quasi) experiments had been conducted. The following literature review evaluates the state of the art of olfactory marketing and retailing research with reference to the applied research designs. 
Table 1: Prior studies of the effects of ambient scent

\begin{tabular}{|c|c|c|c|c|c|c|}
\hline Source & $\begin{array}{l}\text { Independent } \\
\text { variable }\end{array}$ & $\begin{array}{l}\text { Dependent variable } \\
\text { [Mediators] }\end{array}$ & Experimental design & Test units and sample size (n) & $\begin{array}{l}\text { Research } \\
\text { context }\end{array}$ & $\begin{array}{l}\text { Significant (direct) positive } \\
\text { effect }\end{array}$ \\
\hline $\begin{array}{l}\text { Knasko } \\
(1989)\end{array}$ & $\begin{array}{l}2 \text { ambient } \\
\text { scents }\end{array}$ & $\begin{array}{l}\text { Spending, interaction with sales clerks, } \\
\text { touching frequency of displays, } \\
\text { retention time, [gender] }\end{array}$ & Field experiment, (observation) & $\begin{array}{l}\text { All actual shoppers over a period of } \\
\text { two weeks }\end{array}$ & Store & $\begin{array}{l}\text { Retention time, spending, only } \\
\text { for fruity/floral ambient scent }\end{array}$ \\
\hline $\begin{array}{l}\text { Bone \& Jantrania } \\
\text { (1992) }\end{array}$ & $\begin{array}{l}2 \text { ambient } \\
\text { scents }\end{array}$ & $\begin{array}{l}\text { Overall product evaluation } \\
\text { Evaluation of product attributes }\end{array}$ & $\begin{array}{l}\text { Laboratory experiment, static } \\
\text { group comparison, (survey) }\end{array}$ & Students (53) & Product & Overall product evaluation \\
\hline $\begin{array}{l}\text { Hirsch } \\
(1995)\end{array}$ & $\begin{array}{l}2 \text { ambient } \\
\text { scents }\end{array}$ & Spending & Field experiment, (observation) & $\begin{array}{l}\text { Actual gamblers at } 18 \text { slot } \\
\text { machines (over three weekends } \\
\text { (Saturday, Sunday) }\end{array}$ & Casino & $\begin{array}{l}\text { Spending, only for one ambient } \\
\text { scent }\end{array}$ \\
\hline $\begin{array}{l}\text { Mitchell et al. } \\
\text { (1995) }\end{array}$ & $\begin{array}{l}\text { Ambient } \\
\text { scent, product }\end{array}$ & $\begin{array}{l}\text { Memory, information search, variety } \\
\text { seeking behaviour, product choice }\end{array}$ & $\begin{array}{l}\text { Laboratory experiment, static } \\
\text { group comparison (survey) }\end{array}$ & $\begin{array}{l}\text { Experiment 1: Students; } \mathrm{n}, 77 \text {; } \\
\text { Experiment } 2: \text { no characterisation, } \\
\mathrm{n}, 78\end{array}$ & Product & $\begin{array}{l}\text { Attention, variety seeking, } \\
\text { information search, choice } \\
\text { process, when ambient scent is } \\
\text { congruent with product class }\end{array}$ \\
\hline $\begin{array}{l}\text { Spangenberg et al. } \\
\text { (1996) }\end{array}$ & $\begin{array}{l}2 \text { ambient } \\
\text { scents }\end{array}$ & $\begin{array}{l}\text { Evaluation of store, store environment, } \\
\text { merchandise, specific products, } \\
\text { patronage intention, buying intention, } \\
\text { actual vs. perceived time spent, number } \\
\text { of products examined }\end{array}$ & $\begin{array}{l}\text { Laboratory experiment, static } \\
\text { group comparison, (survey and } \\
\text { observation) }\end{array}$ & $\begin{array}{l}\text { Convenience sample including } \\
\text { mostly students }(\mathrm{n}, 704)\end{array}$ & $\begin{array}{l}\text { Store and } \\
\text { product }\end{array}$ & $\begin{array}{l}\text { Perception of store attributes, } \\
\text { perception of store environment, } \\
\text { perception of merchandise, } \\
\text { purchase intention, retention time }\end{array}$ \\
\hline $\begin{array}{l}\text { Morrin \& Ratneshwar } \\
\text { (2000) }\end{array}$ & $\begin{array}{l}\text { Ambient } \\
\text { scent }\end{array}$ & $\begin{array}{l}\text { Pleasure/arousal/dominance, brand } \\
\text { perception, attention, memory }\end{array}$ & $\begin{array}{l}\text { Laboratory experiment, static } \\
\text { group comparison (survey and } \\
\text { observation) }\end{array}$ & Students $(\mathrm{n}, 50)$ & Brands & $\begin{array}{l}\text { Brand evaluation time, recall (for } \\
\text { unfamiliar brands) }\end{array}$ \\
\hline $\begin{array}{l}\text { Mattila \& Wirtz } \\
(2001)\end{array}$ & $\begin{array}{l}\text { Ambient } \\
\text { scent, music }\end{array}$ & $\begin{array}{l}\text { Pleasure/arousal, approach/avoidance, } \\
\text { store environment, satisfaction }\end{array}$ & $\begin{array}{l}\text { Field experiment, static group } \\
\text { comparison (survey and } \\
\text { observation) }\end{array}$ & Actual shoppers (n, 270) & Store & $\begin{array}{l}\text { Perception of store environment, } \\
\text { impulse buying, satisfaction, only } \\
\text { when music and ambient scent } \\
\text { are congruent }\end{array}$ \\
\hline $\begin{array}{l}\text { Chebat \& Michon } \\
\text { (2003) }\end{array}$ & $\begin{array}{l}\text { Ambient } \\
\text { scent }\end{array}$ & $\begin{array}{l}\text { Pleasure/arousal, mall perception, } \\
\text { product quality, spending }\end{array}$ & $\begin{array}{l}\text { Field experiment, after only with } \\
\text { control group design (survey) }\end{array}$ & $\begin{array}{l}\text { Actual shoppers (experimental } \\
\text { group: } \mathrm{n}, 145 \text {; control group: } \mathrm{n} \text {, } \\
447 \text { ) }\end{array}$ & $\begin{array}{l}\text { Community } \\
\text { mall }\end{array}$ & $\begin{array}{l}\text { Mall perception (low), product } \\
\text { quality (low) }\end{array}$ \\
\hline $\begin{array}{l}\text { Michon et al. } \\
\text { (2005) }\end{array}$ & $\begin{array}{l}\text { Ambient } \\
\text { scent }\end{array}$ & $\begin{array}{l}\text { Mall perception, pleasure } \\
\text { product quality perception, [retail } \\
\text { density] }\end{array}$ & $\begin{array}{l}\text { Field experiment, After only with } \\
\text { control group design (survey) }\end{array}$ & Actual shoppers $(\mathrm{n}, 9 \times 31,279)$ & $\begin{array}{l}\text { Community } \\
\text { mall }\end{array}$ & $\begin{array}{l}\text { Mall perception (medium), only } \\
\text { at a medium density level }\end{array}$ \\
\hline $\begin{array}{l}\text { Orth \& Bourrain } \\
(2005)\end{array}$ & $\begin{array}{l}\text { Pleasant and } \\
\text { unpleasant } \\
\text { ambient scent }\end{array}$ & $\begin{array}{l}\text { Actual/optimum stimulation level, risk } \\
\text { taking, variety seeking, curiosity- } \\
\text { motivated behaviour }\end{array}$ & $\begin{array}{l}\text { Laboratory experiment, after only } \\
\text { with control group design } \\
\text { (survey) }\end{array}$ & $\begin{array}{l}\text { Persons from a consumer panel (n, } \\
248 \text { ) }\end{array}$ & $\begin{array}{l}\text { Store and } \\
\text { product }\end{array}$ & $\begin{array}{l}\text { Actual stimulation, only for } \\
\text { pleasant ambient scent, risk } \\
\text { taking and variety seeking, only } \\
\text { for unpleasant ambient scent, } \\
\text { curiosity-motivated behaviour }\end{array}$ \\
\hline $\begin{array}{l}\text { Gueguen \& Petr } \\
\text { (2006) }\end{array}$ & $\begin{array}{l}2 \text { ambient } \\
\text { scents }\end{array}$ & Retention time, spending & Field experiment, (observation) & $\begin{array}{l}\text { All actual shoppers over a period of } \\
\text { two weeks }(n, 88)\end{array}$ & Restaurant & $\begin{array}{l}\text { Retention time, spending, (only } \\
\text { for lavender) }\end{array}$ \\
\hline
\end{tabular}




\section{Research context}

Whereas older publications (pre-2003) look at the effectiveness of ambient scent in a product and/or store context, more recent studies focus on the supra-store context of shopping malls (Chebat \& Michon, 2003; Michon et al., 2005). This might be because of the rising number of such retail (agglomeration) formats and preference of both consumers and retailers for these retail environments. Furthermore, atmosphere (as a set of stimuli) has been identified to be of determinant importance for retail agglomeration attractiveness (e.g. Teller, 2008; Teller \& Reutterer, 2008; Teller \& Elms, 2009 and 2010). Nonetheless, the complexity of identifying and measuring relationships between an ambient scent and a consumer response increases due to the high number of extraneous variables such as other atmospheric stimuli and/or the heterogeneity of different kinds of clientele patronising different stores located within an agglomeration (van Kenhove, de Wulf, \& van Waterschoot, 1999; Teller \& Reutterer, 2008).

\section{Experimental location and test units}

A considerable number of publications investigate the phenomenon in a product and brand context by conducting laboratory experiments and using students as their test units (Bone \& Jantrania, 1992; Mitchel et al., 1995; Spangenberg et al., 1996; Morrin \& Ratneshwar, 2000; Orth \& Bourrain, 2005). The applied experimental approach offers a high control of the research environment, leading to a high internal validity and consequently is time- and costeffective in particular when the participants are students (Malhotra \& Birks, 2007). On the other hand, such an artificial research environment causes reactive errors or measurement artefacts and, furthermore, the external validity is limited because of the focus on a very specific consumer group, i.e. students of a particular university (Malhotra \& Birks, 2007). In 
other words, the findings in terms of the effectiveness of ambient scent can hardly be extrapolated to other populations and thus have a more exploratory character.

\section{Sample selection procedure}

Although most of the identified publications include actual customers as test units, the authors of only three studies stated that their sample had been selected randomly (Chebat \& Michon, 2003; Michon et al., 2005; Orth \& Bourrain, 2005). In another three studies the whole population was observed over the defined research period (Knasko, 1989; Hirsch, 1995; Gueguen \& Petr, 2006). A convenience sampling approach was applied in all the others, such that the results could be affected by sample selection bias and cannot be seen as representative for a wider population.

\section{Experimental design}

All research designs investigate the effects of ambient scent by observing and/or surveying two groups of test units. One group that had been exposed to the stimulus (i.e. experimental group) and one group that had not (i.e. control group). Thus, the design which applied the random sampling technique can be seen as a true experimental design, denoted as the 'after only with control group' whereas all the others are 'static group comparison'. Due to the lack of randomisation of the selection procedure this latter pre-experimental design fails to control the above mentioned 'extraneous' variables which are quite numerous in a store or even agglomeration context. The 'after only with control group' design does not - theoretically suffer from this problem although it is sensitive with respect to sample mortality and selection bias (Malhotra \& Birks, 2007). Even more critical is the underlying assumption that the randomly selected groups are equal in any particular respect with respect to the pre-treatment 
measures (Malhotra \& Birks, 2007). Since there is no pre- or before-measurement this assumption is left unproven. In a store or agglomeration context a considerable number of variables, e.g. demographic, psychographic and attitudinal variables, can act as moderators on the investigated effects if they are different between the control and experimental group (Gulas \& Bloch, 1995; Bone \& Ellen, 1999).

The only way to confirm this assumption of group homogeneity is to apply a 'before-after with control group design' which has not been used in any of the aforementioned articles. Finally, it is worth mentioning that only few publications consider selective moderators like music (Mattila \& Wirtz, 2001), retail density (Michon et al., 2005) or pleasantness of scent (Orth \& Bourrain, 2005).

\section{Endogenous variables}

The ambient scents (exogenous variables) used in most studies were citrus (pleasing, arousing or stimulating) and lavender (neutral) (based on the findings of Spangenberg et al., 1996). The endogenous variables proposed to be directly or indirectly affected can be divided into three groups:

- Perceptional/attitudinal variables: overall perception or perception of certain attributes (i.e. quality) of products, stores or malls, store environment;

- Emotional variables: pleasure, arousal, stimulation level;

- Behavioural and intentional variables: actual and perceived spending and retention time, intended spending and retention time, variety-seeking and curiosity-motivated behaviour, information search, choice behaviour. 
The inclusion of these above variables depended on the (implicit) research question of each study and also on the theoretical framework applied. Additionally, the operationalisation of variables varied across the different studies. Therefore, it is difficult to compare and confirm the identified effects as significant or insignificant.

Referring back to the previous section, the measurement of changes in the endogenous variables caused by the exogenous variables is problematic if there is no pre-measurement. For example changes in the emotional state, e.g. pleasure or arousal, can be different for each test unit (person) before they are exposed to the experimental treatment. The same is true for the attitude and historic perception of attributes of an investigated object, e.g. store. Furthermore, the individual shopping situation and task or personal characteristics like disposable income can predetermine the shopping behaviour in the experimental environment (e.g. Kahn \& Schmittlein, 1992; van Kenhove et al., 1999). Thus, a causal interpretation of differences between a control and an experimental group with respect to the stimulus might be affected by such preliminary differences between test units. Since in none of the studies did a pre-measurement take place, the causalities of the investigated effects are to some degree questionable.

Concluding the discussion of the identified literature and applied experimental approaches, it can be said that more recent publications apply more rigorous approaches by utilising random sampling (Chebat \& Michon, 2003; Michon et al., 2005; Orth \& Bourrain, 2005). Notwithstanding, the problem of measuring the effectiveness of ambient scent in a retail environment calls for a more complex and consequently more laborious experimental design that incorporates a pre-measurement phase. This is because of the high number of extraneous variables affecting test units and the heterogeneity of test units themselves in terms of 
demographic, psychographic, attitudinal and behavioural variables. In summary, on the basis of prior research, the effectiveness of ambient scent cannot be guaranteed. The evidence and argument above support the call from Neuliep (1991); and Evanschitzky, Baumgaarth, Hubbard and Armstrong (2007) for critical replication studies. The latter cautioned practitioners that 'scientific findings rest upon replication ... few results in marketing have been successfully replicated... given these results, practitioners should be sceptical about making decisions based on the findings of the predominantly single-shot studies reported in the leading marketing journals' $(2007,413)$.

\section{Conceptual framework}

As a basis for a reference study we developed a conceptual framework within which we set up three hypotheses that represent the most frequently investigated effects of ambient scent. The hypotheses are tested by applying the whole spectrum of experimental designs from the previous studies reviewed above.

In the formulation of the hypotheses we focus on a test environment that faces growing preference from consumers' and consequently retailers' points of view - the shopping mall. Recent research demonstrates the extraordinary importance of the perceived atmosphere including scent - on shopping mall attractiveness (Teller, 2008; Teller and Reutterer, 2008; Teller \& Elms, 2009). Furthermore, two of the most rigorous studies conducted in terms of measuring the effectiveness of ambient scent focus on the same research environment. Consequently, the papers of Chebat and Michon (2003) and Michon et al. (2005) serve as templates for both the hypotheses and the empirical research design. 
In line with most of the publications on the effectiveness of ambient scent in a shopping environment (e.g. Spangenberg et al., 1996) we apply the Stimulus-Organism-Response model of Mehrabian and Russell (1974). Therewith, we include two constructs to measure the organism, i.e. perception of the object and emotions of the test units, and one the response, i.e. consumer behaviour (McGoldrick \& Pieros, 1998). Within this conceptual framework we only focus on direct effects between ambient scent and the proposed dependent variables since their existence is crucial for the existence of indirect or mediating effect of emotions or perceptions on shopping behaviour. The most commonly investigated effects can be described as follows.

Bitner (1992) proposes effects of environmental cues, e.g. in terms of atmospherics, on consumers' perceptions and thus evaluation of objects, having an influence of consumers' cognition. More specifically, Spangenberg et al. (1996) proposes and provides empirical proof for ambient scent having an impact on the perception of products and a store. Furthermore, the influence of ambient scent on the perception of a product, a store or a mall was investigated by the studies presented by Bone and Jantrania (1992), Mattila and Wirtz (2001), Chebat and Michon (2003) and Michon et al. (2005). In those studies the effect is measured by the evaluation of object attributes. In terms of a shopping mall these attributes comprise $e . g$. the retail tenant mix, the non-retail tenant mix, price-value ratio and product range of merchandise, personnel and overall atmosphere (Teller, 2008; Teller \& Elms, 2010). The perception of the mall and the evaluation of mall attributes can be seen as a core-determinant of the mall related consumer behaviour (Finn \& Louviere, 1996). We therefore propose the following: 
$H_{1}$ [Stimulus $\rightarrow$ Organism]: Ambient scent has a significant, positive impact on consumers' perception of a shopping mall.

Donovan, Rossiter, Marcoolyn and Nesdale (1994) propose effects between environmental stimuli and emotional states. Within this framework of the modified Mehrabian-Russell environmental psychology model the effects of ambient scent on consumers' emotions were investigated in the studies of Morrin and Ratneshwar (2000), Chebat and Michon (2003) and Michon et al. (2005). In those studies, emotions are seen to have a mediating role and consequently affect the perception of an object or shopping behaviour (Donovan et al., 1994). Most frequently, the latent construct emotions have been operationalised by pleasure and arousal measured by the scale of Mehrabian and Russell (1974). In accordance with Chebat and Michon (2003) we assume that ambient scent has a positive effect on both pleasure and arousal. In the context of a shopping mall we set up our second hypothesis:

$\mathrm{H}_{2}$ [Stimulus $\rightarrow$ Organism]: Ambient scent has a significant, positive impact on consumers' emotions in a shopping mall.

Gulas and Bloch (1995) propose an effect between the use of ambient scent and affective response of consumers in terms of their behaviour. The consumer behaviour as a dependent variable has been considered most frequently in empirical studies although a direct effect was not always proposed (Knasko, 1989; Hirsch, 1995; Spangenberg et al., 1996; Mattila \& Wirtz, 2001; Chebat \& Michon, 2003; Michon et al., 2005; Gueguen \& Petr, 2006). Indicators that are frequently used to operationalise the construct of shopping behaviour in a mall context are (planned or actual): spending in (non-)retail stores; retention time; and number of stores visited. Based on that we derive our final hypothesis: 
$H_{3}$ [Stimulus $\rightarrow$ Response]: Ambient scent has a significant, positive impact on consumers' behaviour in a shopping mall.

To test the hypotheses by using different experimental designs we conducted the following empirical study.

\section{Empirical study}

\section{Experimental design}

A field experiment was conducted in a regional, centrally located shopping mall in a central European city. The particular mall was chosen because of its small size $\left(30,000 \mathrm{~m}^{2}, 40\right.$ tenants, 680 parking spaces, 500 employees) and its design that can be considered as state of the art (ICSC European Shopping Centre Award Winner 2008).

The field experiment contained two steps where we applied a survey approach including observational elements. The applied 'in-vivo' survey approach has the advantage that the phenomenon is investigated in a biotic shopping situation (Teller \& Reutterer, 2008). It enables the researcher to confront respondents with questions about their actual perceptions, emotions and behaviour on the respective shopping trip. Despite the resulting high internal validity of the approach the control of all extraneous factors on the experiment, e.g. weather, mood of the respondents etc., is almost impossible. Nevertheless, we see the disadvantages of the applied approach outweighed by the advantages to investigate the effectiveness in a real life situation (Michon et al., 2005).

In the first step, consumers who entered the mall during a period of one week were surveyed by using an interviewer-administered questionnaire. Thereby we used a time sampling 
approach and selected those consumers who entered the mall every full quarter of an hour and passed an exactly defined point at the entrance area. The number of respondents varied according to the time of day (Sudman, 1980). The test units were confronted with questions concerning their shopping behaviour in the mall in general, about their actual shopping in the mall (including task definition, planned spending, shops to be visited, time to be spent). Thereafter, they had to evaluate their emotional state and the mall based on 52 attributes according to Teller, Reutterer and Schnedlitz (2008). After a self-characterisation based on the demographic and socio-economic questions, respondents were asked to return after they had completed their shopping in that mall. At this stage of the interview, the time was recorded on the questionnaire to obtain objective measures for the retention time. Before leaving the mall, respondents reflected on their shopping trip in the mall based on questions with respect perceived retention time, actual stores visited and emotional state. Finally, they were once more confronted with the same scale of attributes characterising the mall.

The second step of the experiment included the same sampling and interview procedure using the same research instrument. In that second week an ambient scent was spread in the mall. This was arranged by a professional ambient scent marketing agency with wide experience in that field. The terminals were located in the common area of the mall and taking into account the size and air-circulation. No ambient scent was used by all the other 40 tenants and interviewers were (again) told not to wear any perfume (Chebat \& Michon, 2003). The ambient scent consisted of a mixture of orange, grapefruit, bergamot, cinnamon, cardamom, ginger, pimento and other additives. The characteristics of that ambient scent are widely used in comparable retail settings and other studies and are described as warming, stimulating, sweet and citric-like. It is finally worth mentioning that the weather and thus the light intensity did not vary noticeably over the test period (two weeks in June). Overall it can be said that 
there were no major extraneous variables influencing the comparability of the two weeks in terms of the use and effectiveness of the used ambient scent.

One hundred and thirty-six usable questionnaires were obtained from the 'control group' where no ambient scent was used and 176 from the 'experimental group' which was exposed to the ambient scent. The sample mortality included 38 respondents who were reluctant to answer the questions after their visit. This group turns out not to be significantly different to the final sample with respect to the data collected in the pre-measurement. At no stage of the interviews were the respondents told about the aim of the study, i.e. test the effectiveness of ambient scent.

\section{Characterisation of respondent groups}

The two respondent groups can be regarded as homogenous with respect to their demographics and shopping behaviour in the mall since no significant differences could be identified (see Table 2). Due to the 'in vivo' survey approach and the sampling procedure, the selected groups of consumers do not totally reflect the demographic structure of the whole population of the urban area. The surveyed clientele of the mall can be characterised by being dominated by women and highly educated. The sample contains a remarkably large group of students and senior citizens (see also the standard deviation of the age figure) which can be explained by the demographic structure of the specific district in which the mall is located. Our respondents were experienced shoppers with respect to the mall since, on average, they spend more than 6 visits per month there, stay longer than three quarters of an hour per visit and shop at more than two outlets there. 
Table 2: Respondents' profile

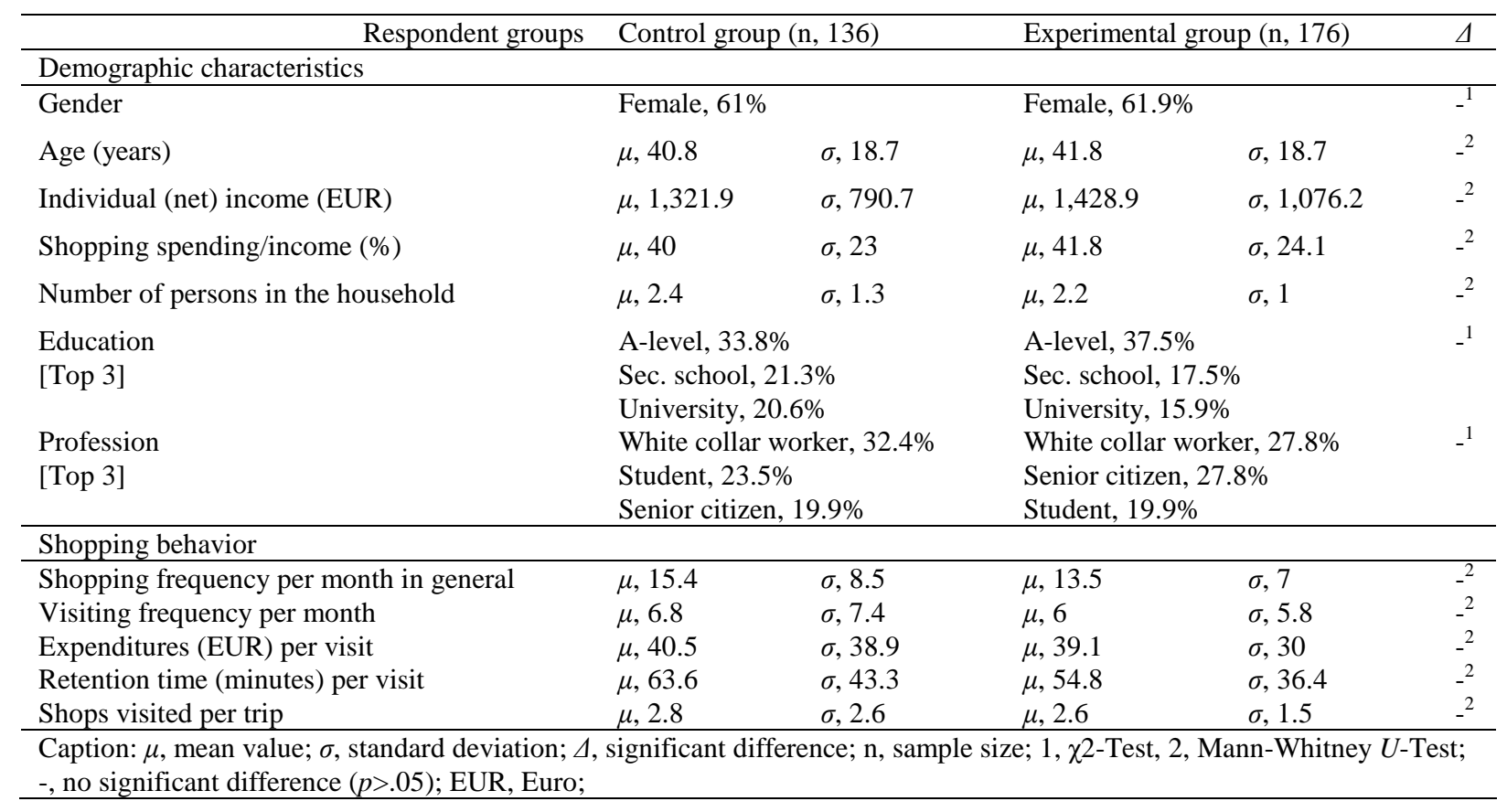

Analysis

Simulated experimental designs: Despite the theoretical and empirical foundations of the three hypotheses, methodological problems can be identified in some prior studies. Thus the accuracy of the supporting results is to be questioned on the basis of (1) the lack of controlling extraneous variables which are numerous in such a complex retail environment like a store or a shopping mall and (2) the lack of testing the homogeneity-assumption with respect to the two groups of test units (i.e. experimental and control group).

The data derived from our empirical study enables us to test the hypotheses as if by different experimental designs (see Figure 1). The most basic can be denoted as 'one group pretestposttest' design. Although this test has not been applied in any of the identified prior studies varying results compared to the other two designs reveal the impact of extraneous variables. The effect of the stimulus is investigated by looking at differences between the pre- and postmeasurement of the dependent variables $(\Delta 1)$. The 'posttest only control group design' 
investigates the differences between the control and the experimental group with respect to the proposed dependent variables $(\Delta 2)$. This would correspond to the 'static group design' if no random sampling procedure was adapted. The last and most extensive approach is the 'pretest-posttest control group' where the differences between the control group $\left(\triangle 3_{\mathrm{a}}\right)$ and the experimental group $\left(\triangle 3_{\mathrm{b}}\right)$ are compared $(\triangle 3)$. There, the group-homogeneity can be tested by looking at the differences in the pre-measurement $\left(\Delta 3_{0}\right)$.

Figure 1: Comparison of the experimental designs used in this study

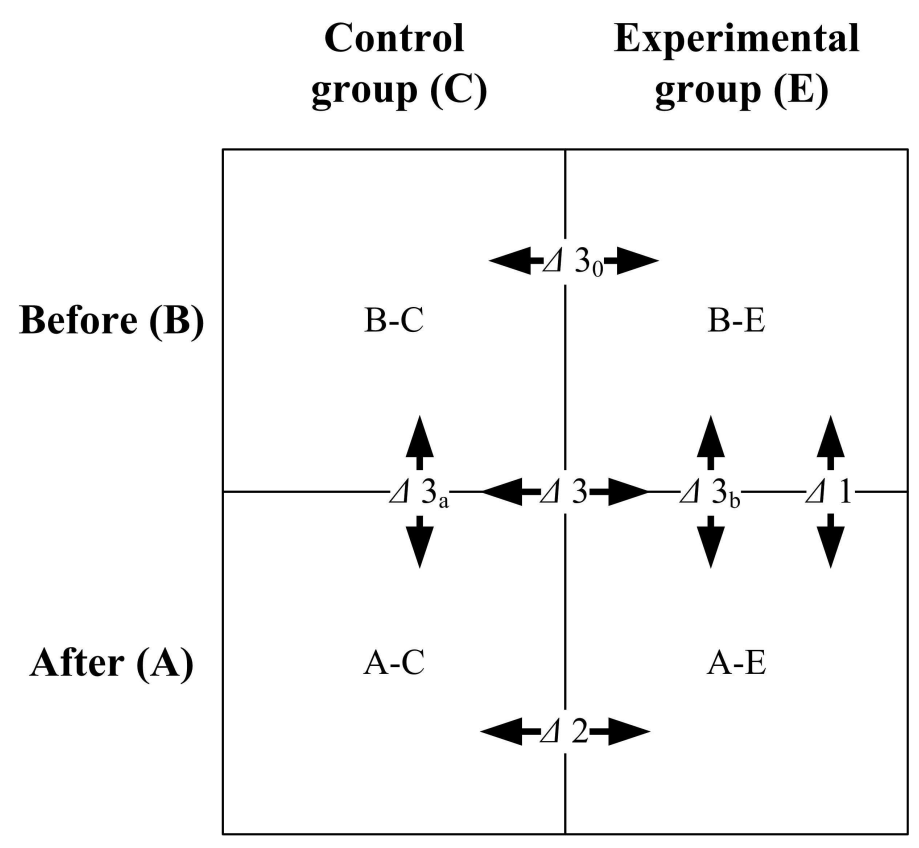

Tests of significance: Mean values were calculated of all items standing behind the perceptual and emotional (latent) variables. This procedure can be justified by the satisfactory internal consistency of each variable (Cronbach's alpha around or above 0.70; see Appendix). In order to identify an effect of the olfactory stimulus, rank-sum tests were conducted between the variable or values of the respective groups. For independent samples, e.g. comparison between the experimental and the control group, we applied the Mann-Whitney $U$-Test. The WilcoxonTest was used for dependent samples, e.g. comparison of the before and after evaluation of the experimental group. The use of these particular statistical tests was motivated by the ordinal 
or 'only' quasi-metric measurement level of the applied rating scales and fewer assumptions regarding the distribution assumption of our data - in particular with respect to the behavioural variables (Field, 2009).

\section{Results}

One group pretest-posttest design ( $\Delta 1)$

First, only the experimental group is taken into account and the perception of mall attributes, respondents' emotions and shopping behaviour is compared between the pre- and postmeasurement (see Table 3).

Table 3: Results from the 'one group pretest-posttest design'

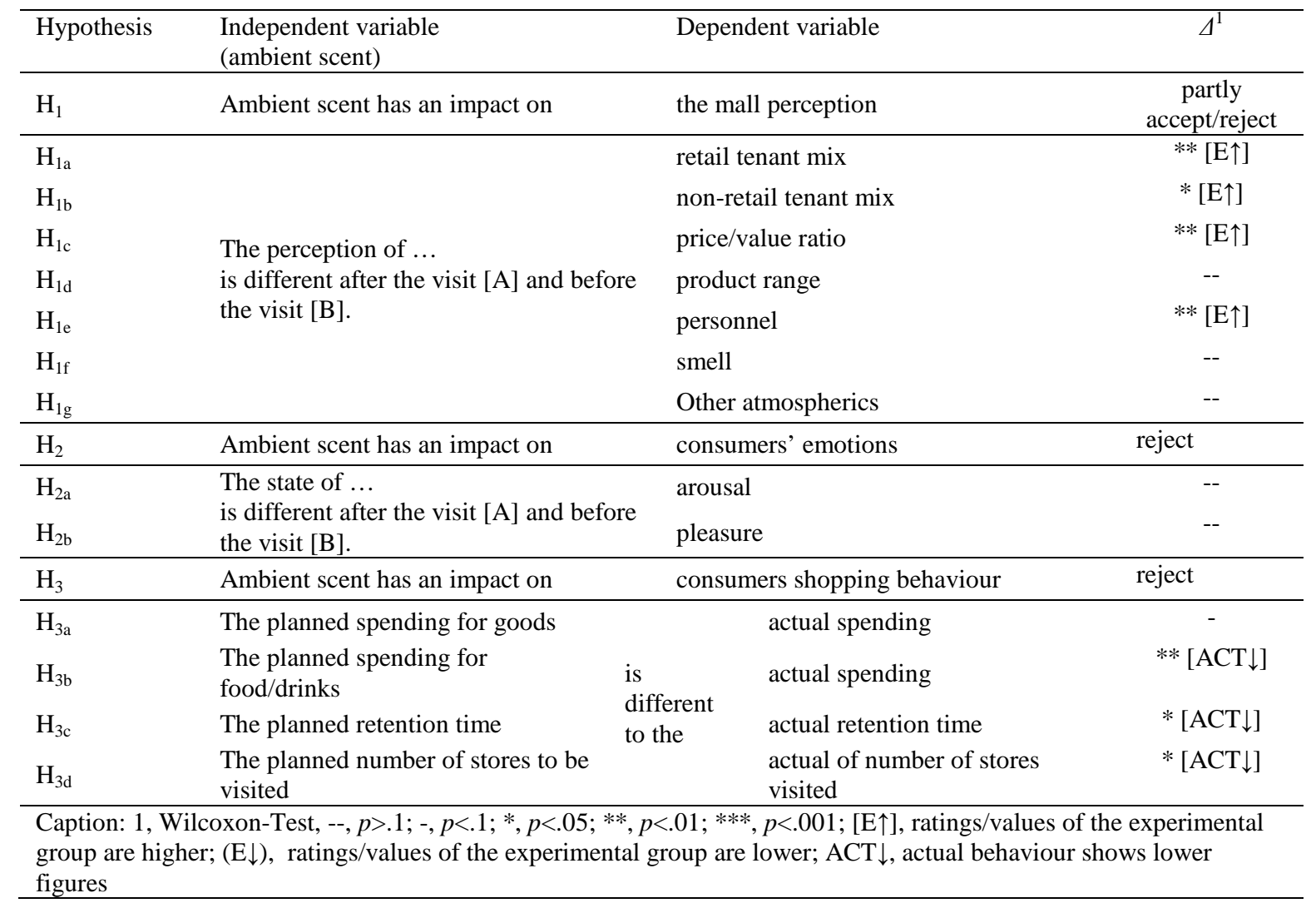

It can be seen that the ratings of the 'retail tenant mix', the 'non-retail tenant mix', the 'pricevalue ratio' and the 'personnel' of the mall are rated significantly higher after the visit to the 
mall than before (Wilcoxon-Test; $p<.05$ ). Pleasure and arousal did not change during the visit. Interestingly, the shopping behaviour shows significant changes but not in favour of the mall tenants. The actual spending for food and drinks, the actual retention time and the actual number of stores visited was significantly lower than had been planned when entering the mall. Consequently, only $\mathrm{H}_{1}$ can be confirmed with respect to the significant variables.

Again, it needs to be mentioned that although significant differences are investigated, these results cannot necessarily be interpreted as demonstrating that the ambient scent caused these changes during the mall visit - as we will demonstrate with the 'pretest-posttest control group design' in the section, below.

'Posttest only control group design' ( $\triangle 2$ 2)

This design requires the inclusion of the results of the control group (see Table 4). Again we see that selected perceptual variables show significant differences (Mann-Whitney $U$-Test). The '(non-)retail tenant mix', the 'product range', 'personnel' and 'other atmospherics' were rated higher by the experimental group. Furthermore the test units of the scented group feel significantly more aroused. No differences regarding the behavioural variables can be identified except the number of stores visited, which is significantly higher for the control group.

This design can be considered as the most sophisticated one presented in prior literature and on that basis, $\mathrm{H}_{1}$ and $\mathrm{H}_{2}$ would be partially supported. Nevertheless, since no premeasurement is included in investigating the 'causal' effect of the olfactory stimulus, the homogeneity of the control and experimental group can only be assumed but is left unproven. 
Therefore, we do not accept $\mathrm{H}_{1}$ and $\mathrm{H}_{2}$ as partially supported but rather, turn to the "pretestposttest control group design' below.

Table 4: Results from the 'posttest only control group design'

\begin{tabular}{|c|c|c|c|}
\hline Hypothesis & $\begin{array}{l}\text { Independent variable } \\
\text { (ambient scent) }\end{array}$ & Dependent variable & $\Delta^{1}$ \\
\hline $\mathrm{H}_{1}$ & Ambient scent has an impact on & the mall perception & $\begin{array}{c}\text { partly } \\
\text { accept/reject }\end{array}$ \\
\hline $\mathrm{H}_{1 \mathrm{a}}$ & \multirow{7}{*}{$\begin{array}{l}\text { The experimental group [E] differs from } \\
\text { the control group [C] with respect to the } \\
\text { perception of the }\end{array}$} & retail tenant mix & $*[\mathrm{E} \uparrow]$ \\
\hline $\mathrm{H}_{1 \mathrm{~b}}$ & & non-retail tenant mix & $*[\mathrm{E} \uparrow]$ \\
\hline $\mathrm{H}_{1 \mathrm{c}}$ & & price/value ratio & -- \\
\hline $\mathrm{H}_{1 \mathrm{~d}}$ & & product range & $* *[\mathrm{E} \uparrow]$ \\
\hline $\mathrm{H}_{1 \mathrm{e}}$ & & personnel & $* * *[\mathrm{E} \uparrow]$ \\
\hline $\mathrm{H}_{1 \mathrm{f}}$ & & smell & -- \\
\hline $\mathrm{H}_{1 \mathrm{~g}}$ & & other atmospherics & $*[\mathrm{E} \uparrow]$ \\
\hline $\mathrm{H}_{2}$ & Ambient scent has an impact on & consumers' emotions & $\begin{array}{c}\text { partly } \\
\text { accept/reject }\end{array}$ \\
\hline $\mathrm{H}_{2 \mathrm{a}}$ & \multirow{2}{*}{$\begin{array}{l}\text { The experimental group [E] differs from } \\
\text { the control group [C] with respect to } \\
\text { their state of }\end{array}$} & arousal & $* *[\mathrm{E} \uparrow]$ \\
\hline $\mathrm{H}_{2 \mathrm{~b}}$ & & pleasure & -- \\
\hline $\mathrm{H}_{3}$ & Ambient scent has an impact on & consumers actual shopping behaviour & reject \\
\hline $\mathrm{H}_{3 \mathrm{a}}$ & \multirow{6}{*}{$\begin{array}{l}\text { The experimental group [E] differs from } \\
\text { the control group [C] with respect to }\end{array}$} & actual spending for goods & -- \\
\hline $\mathrm{H}_{3 \mathrm{~b}}$ & & actual spending for food/drinks & -- \\
\hline $\mathrm{H}_{3 \mathrm{c}}$ & & actual retention time & -- \\
\hline $\mathrm{H}_{3 \mathrm{~d}}$ & & perceived retention time & -- \\
\hline $\mathrm{H}_{3 \mathrm{e}}$ & & actual number of stores visited & $* *(\mathrm{E} \downarrow)$ \\
\hline $\mathrm{H}_{3 \mathrm{e}}$ & & $\begin{array}{l}\text { actual number of stores visited where } \\
\text { money was spent }\end{array}$ & -- \\
\hline
\end{tabular}

\section{'Pretest-posttest control group design' (4 3)}

The final design incorporates both a pre-measurement and a control group. Before presenting the results from comparing the changes observed $\left(\Delta 3_{\mathrm{a}}\right.$ and $\left.\Delta 3_{\mathrm{b}}\right)$ between the two groups, the homogeneity assumption is tested with respect to a broad set of characterising variables $\left(\Delta 3_{0}\right)$. In other words we investigate whether the random sampling approach really produced two homogenous samples - in any relevant respect.

By applying simple bivariate statistical methods we see that the control and experimental premeasurement groups are homogenous ( $p>.1)$ with respect to the following variables: 
- Personal characteristics (see Table 2);

- Average shopping behaviour related to the mall under investigation;

- Shopping situation: task definition ( $\chi^{2}$-Test; according to van Kenhove et al., 1999), involvement (Mann-Whitney $U$-Test, scale according to Wakefield \& Baker, 1998)

- Overall perception of mall attractiveness: satisfaction, retention proneness and patronage intention (Mann-Whitney $U$-Test, scales according to Teller \& Reutterer, 2008);

- Planned shopping behaviour on site: spending, number of stores to be visited (MannWhitney $U$-Test);

- Perception of mall attributes: non-retail tenant mix, price-value ratio, smell and other atmospheric stimuli (Mann-Whitney $U$-Test);

- State of emotions: pleasure (Mann-Whitney $U$-Test).

Nevertheless, we have to reject the group-homogeneity assumption because we face the following significant differences $(p>.1)$ :

- Planned shopping behaviour on site: retention time (higher ratings in the control group, Mann-Whitney $U$-Test);

- Perception of mall attributes: retail tenant mix, product range, personnel (higher ratings in the experimental group, Mann-Whitney $U$-Test);

- State of emotions: arousal (higher ratings in the experimental group, Mann-Whitney $U$-Test).

It can be concluded that the homogeneity assumption cannot be confirmed for five variables included in the conceptual model. Recall, interestingly, that all perceptual variables and the emotional variable turned out to be affected by ambient scent when tested with respect to the ‘posttest only control group design'. Consequently, those results are questionable. 
Pretest-posttest control group design is not sensitive to this heterogeneity because the premeasurement serves as a baseline or reference value for each test unit. The effect of ambient scent is then investigated by first calculating the differences between the post-measurement and the reference value for both groups and then comparing these values between the groups (Table 5).

Table 5: Pretest-posttest control group design'

\begin{tabular}{|c|c|c|c|}
\hline Hypothesis & $\begin{array}{l}\text { Independent variable } \\
\text { (ambient scent) }\end{array}$ & Dependent variable & $\Delta^{1}$ \\
\hline $\mathrm{H}_{1}$ & Ambient scent has an impact on & the mall perception & reject \\
\hline $\mathrm{H}_{1 \mathrm{a}}$ & \multirow{7}{*}{$\begin{array}{l}\text { The experimental groups differs from } \\
\text { the control group with respect to } \\
\text { changes of perception of the } . .\end{array}$} & retail tenant mix & -- \\
\hline $\mathrm{H}_{1 \mathrm{~b}}$ & & non-retail tenant mix & - \\
\hline $\mathrm{H}_{1 \mathrm{c}}$ & & price/value ratio & -- \\
\hline $\mathrm{H}_{1 \mathrm{~d}}$ & & product range & -- \\
\hline $\mathrm{H}_{1 \mathrm{e}}$ & & personnel & -- \\
\hline $\mathrm{H}_{1 \mathrm{f}}$ & & ambient scent & -- \\
\hline $\mathrm{H}_{1 \mathrm{~g}}$ & & Other atmospherics & -- \\
\hline $\mathrm{H}_{2}$ & Ambient scent has an impact on & consumers' emotions & reject \\
\hline $\mathrm{H}_{2 \mathrm{a}}$ & \multirow{2}{*}{$\begin{array}{l}\text { The experimental groups differs from } \\
\text { the control group with respect to } \\
\text { changes of their state of ... }\end{array}$} & arousal & -- \\
\hline $\mathrm{H}_{2 \mathrm{~b}}$ & & pleasure & -- \\
\hline $\mathrm{H}_{3}$ & Ambient scent has an impact on & consumers actual shopping behaviour & reject \\
\hline $\mathrm{H}_{3 \mathrm{a}}$ & \multirow{3}{*}{$\begin{array}{l}\text { The experimental groups differs from } \\
\text { the control group with respect to } \\
\text { changes between }\end{array}$} & Planned and actual spending & -- \\
\hline $\mathrm{H}_{3 \mathrm{~b}}$ & & Planned and actual retention time & -- \\
\hline $\mathrm{H}_{3 \mathrm{c}}$ & & $\begin{array}{l}\text { Planned and actual number of stores (to } \\
\text { be) visited }\end{array}$ & $*(\mathrm{E} \downarrow)$ \\
\hline
\end{tabular}

The results of the pretest-posttest control group design are sobering since non of the variables are significantly different in favour of the experimental group. The experimental test units actually visit less shops than they planned compared to their counterparts in the control group.

We also investigated whether positive (significant) results can be found from exemplar demographic segments such as gender, age or educational level. In general the findings were similar within the segments. In gender for instance the only significant differences for the males (n, 120) was that ambient scent only had a positive impact on non-retail tenant mix 
$(p<.01)$ and retention time $(p<.05)$. Whereas for the females $(\mathrm{n}, 192)$ there was a negative effect on the number of stores visited $(p<.05)$. For the age 25 and younger segment $(\mathrm{n}, 85)$ the ambient scent had a positive influence with respect to the perception of the ambient scent only $(p<.05)$, whereas the 50 and older $(\mathrm{n}, 108)$ the effect was negative for the number of stores visited. For educational level the effect of ambient scent was negative for higher educational level $(\mathrm{n}, 190)$ and for the number of stores visited $(p<.05)$.

The varying results derived from the application of the three experimental designs leads us to conclude that the experimental design impacts the results derived from testing the other hypotheses. There were few differences in the findings between the different demographic segments, notwithstanding the occasional positives. Overall there was little positive influence of ambient scent for any of the demographic segments.

The most interesting segmentation findings come from the post-hoc segments considering ambient scent not very important (rating between 0 and $6(\mathrm{n}, 109) v s$. very important (rating between 7 and $9(n, 203))$. As might be expected there were negative findings on the effect of ambient scent on spending and number of stores visited $(p<.05)$ for those respondents for whom ambient scent was considered unimportant. Even for those for whom ambient scent was considered important, the only significant positive effect was on the perception of the non-retail tenant mix.

\section{Conclusions}

Taking into consideration the specific characteristics of the research object, i.e. shopping mall, the results confirm some of the findings from literature depending on the simulated experimental design. An overview of the hypotheses testing can be viewed in Table 6 . 
Table 6: Synopsis of hypotheses testing

\begin{tabular}{|c|c|c|c|}
\hline Experimental design & $\begin{array}{c}\text { One group pretest-posttest } \\
\text { design }\end{array}$ & $\begin{array}{l}\text { After-only with control } \\
\text { group }\end{array}$ & $\begin{array}{l}\text { Before-after with control } \\
\text { group design }\end{array}$ \\
\hline \multicolumn{4}{|l|}{ Hypotheses } \\
\hline \multicolumn{4}{|l|}{ Ambient scent has an impact on } \\
\hline $\mathrm{H}_{1}$ : perception of the mall & $\begin{array}{l}\text { supported } \\
\text { (partially) }\end{array}$ & $\begin{array}{l}\text { supported } \\
\text { (partially) }\end{array}$ & rejected \\
\hline $\mathrm{H}_{2}$ : state of emotions & rejected & $\begin{array}{l}\text { supported } \\
\text { (partially) }\end{array}$ & rejected \\
\hline $\mathrm{H}_{3}$ : shopping behaviour & rejected & rejected & rejected \\
\hline
\end{tabular}

The most explicit finding is that ambient scent did not affect any observed or surveyed variable of consumer behaviour - no matter which experimental design was simulated. This clearly contradicts the findings from Knasko (1989), Spangenberg et al. (1996), Hirsch (1995), Mattila and Wirtz (2001) and Gueguen and Petr (2006). Since no effect was identified for our 'before-after with control group design', a depth of rigour that has not been applied previously in this context, prior research that proposes indirect effects of ambient scent on behaviour also need to be treated with caution. Nonetheless, previous findings can be confirmed for the 'post-test only with control group design' (e.g. Chebat \& Michon, 2003; Michon et al., 2005) and also where no pre-measurement had been included (e.g. Bone \& Jantrania, 1992; Spangenberg et al., 1996).

At the first sight, these results seem to be ambiguous but ultimately demonstrate how determinant the applied measurement approach is for the effects identified. The differences between the pre-experimental design and the most sophisticated design clearly show the strong effect from the numerous extraneous variables which in particular include other atmospheric stimuli in a mall. Consequently, the measurement of atmospheric stimuli without including a control group may result in false apparent support for hypotheses. Regarding the 'post-measurement only with control group' we have identified an even more substantial issue. The random sampling approach seemed at the outset to produce two homogenous subsamples, i.e. the control and the experimental group. They are invariant in terms of a number 
of variables like demographics, average shopping behaviour and the variables operationalising the shopping situation. The two groups show significant differences with respect to the dependent variables which might appear to be related to significant differences in five perceptual variables and one emotional variable. Nevertheless, by comparing with the result from the 'pre-posttest with control group design' it is clear that we are again confronted with false support for the hypotheses. As an aside we note that some prior work reports positive findings for particular demographic segments. Indeed these findings also indicate differences but when the most rigorous design is used our interpretation is that these differences are insufficient to conclude a positive effect of ambient scent. As a result, it can be concluded that the application of different experimental designs substantially affects the results.

Since none of the studies identified in academic literature incorporates a pre-measurement in identifying the effectiveness of the ambient scent used, we may question the conclusions that they report. This is especially true for those studies where a static group comparison had been used in studying the effectiveness or ineffectiveness of ambient scent. I.e., results showing no effect of ambient scent on the dependent variables might also be different if a baseline measurement had been included. Indeed, perhaps as would be expected we find a difference with respect to the impact of ambient scent between the respondents considering ambient scent as important in contrast to those considering ambient scent as unimportant, viz. for a full one third of the sample ambient scent had an negative impact on consumer behaviour.

Finally, we do not conclude that prior findings from studies where 'post-test only with control group' was applied are wrong but rather that they need to be treated with care since the group homogeneity assumption did not appear to have been demonstrated. By referring back to our research question we tend towards a conclusion that ambient scent has no impact on either 
perception, emotions or behaviour of consumers. Nevertheless, the following limitations need to be taken into account when interpreting our finding.

\section{Limitations and outlook}

Due to the specific character of retail settings with respect to different geographical areas and times of the year, the findings suffer from limited external validity. Although a random sampling approach was used, the results can only be generalised to the clientele of the investigated regional mall over the research period.

In accordance with the purpose of our study and the sample sizes, we did not distinguish between certain consumer segments apart from those differentiated by gender, age and educational level. Therefore, it is possible that specific groups identifiable by other demographic, psychographic variables (e.g. hedonic or utilitarian shopping orientation) or behavioural characteristics (e.g. frequent or infrequent shoppers) might show different reactions to the ambient scent (Bitner, 1992).

The particular ambient scent used for this study can also be seen as a limitation. According to Gulas and Bloch (1995), scent preference or experience can moderate the effects investigated. That said, we were reluctant to use a different ambient scent to that used in most previous ambient scent studies.

Obviously, a shopping mall includes more atmospheric stimuli compared to a store and thus the effective use of ambient scent turns out to be a quite complex task. The findings might well be different when the research object is a store or a single product. We justify our focus on the mall by the fact that the most rigorous prior studies have been conducted in a mall context and thus were most appropriate to be replicated. 
In summary, this study has explored the replicability of prior studies of the effects of ambient scent in the shopping mall context and concluded that challenges to the findings of positive effects remain. In this instance, our findings do not support previous work on the positive effect of ambient scent although other contexts and other ambient scents could be investigated in the future. We recommend directing resources to more rigorous and extensive investigation than has been applied in the past not just for ambient scent but also in the search for other, perhaps more effective stimuli. Such stimuli might include music, visuals such as colours and in particular anything animated such as digital signage video screens.

\section{References}

Bitner, M. J. (1992). Servicescapes: The impact of physical surroundings on customers and employees. Journal of Marketing, 56, 57-71.

Bone, P. F., \& Ellen, P. S. (1999). Scents in the marketplace: Explaining a fraction of olfaction. Journal of Retailing, 75, 243-262.

Bone, P. F., \& Jantraia, S. (1992). Olfaction as a cue for product quality. Marketing Letters, 3, 289-296.

Chebat, J. C., \& Michon, R. (2003). Impact of ambient odors on mall shoppers' emotions, cognition, and spending: A test of competitive causal theories. Journal of Business Research, 56, 529-539.

Donovan, R. J., Rossiter, J. R., Marcoolyn, G., \& Nesdale, A. (1994). Store atmosphere and purchasing behavior. Journal of Retailing; 70, 283-294.

Evanschitzky, H., Baumgaarth, C., Hubbard, R., \& Armstrong, J. S. (2007). Replication research's disturbing trend. Journal of Business Research, 60, 411-415.

Field, A. (2009). Discovering Statistics Using SPSS. Los Angeles: Sage. 
Finn, A., \& Louviere, J. J. (1996). Shopping center image, consideration, and choice: Anchor store contribution. Journal of Business Research, 35, 241-251.

Gueguen, N., \& Petr, C. (2006). Odors and consumer behavior in a restaurant. International Journal of Hospitality Management, 25, 335-339.

Gulas, C. S., \& Bloch, P. H. (1995). Right under our noses: Ambient scent and consumer responses. Journal of Business and Psychology, 10, 87-98.

Hirsch, A. R. (1995). Effects of ambient odors on slot-machine usage in a Las Vegas casino. Psychology \& Marketing, 12, 585-594.

Kahn, B. E., \& Schmittlein, D. C. (1992). The relationship between purchases made on promotion and shopping trip behavior. Journal of Retailing, 68, 294-315.

Knasko, S. C. (1995). Pleasant odors and congruency: Effects on approach behavior, Chemical Senses, 20, 479-87.

Kotler, P. (1973). Atmospherics as a marketing tool. Journal of Retailing, 49, 48-64.

Malhotra, N. K., \& Birks, D. F. (2007). Marketing Research. An Applied Orientation. Prentice Hall: Pearson.

Mattila, A. S., \& Wirtz, J. (2001). Congruency of scent and music as a driver of in-store evaluations and behaviour. Journal of Retailing, 77, 273-289.

McGoldrick P. J., \& Pieros, C. P. (1998). Atmospheres, pleasure and arousal: The influence of response moderators. Journal of Marketing Management, 14, 173-197.

Mehrabian, A., \& Russell, J. A. (1974). An Approach to Environmental Psychology. Cambridge (MA): MIT-Press.

Michon, R., Chebat, J. C., \& Turley, L. W. (2005). Mall atmospherics: the interaction effects of the mall environment on shopping behavior. Journal of Business Research, 58, 576-583. 
Mitchell, D. J., Kahn, B. E., \& Knasko, S. C. (1995). There's something in the air: Effects of congruent or incongruent ambient odor on consumer decision making. Journal of Consumer Research, 22, 229-238.

Morrin, M., \& Ratneshwar, S. (2000). The effect of retail store environment on retailer performance. Journal of Business Research, 49, 167-81.

Neuliep, W. (1991). Replication Research in the Social Sciences. Los Angeles: Sage.

Orth, U. R., \& Bourrain, A. (2005). Optimum stimulation level theory and the differential impact of olfactory stimuli on consumer exploratory tendencies. Advances in Consumer Research, 32, 613-619.

Spangenberg, E. A., Crowley, A. E., \& Henderson, P. W. (1996). Improving the store environment: Do olfactory cues affect evaluations and behaviors? Journal of Marketing, $60,67-80$

Sudman, S. (1980). Improving the quality of shopping center sampling. Journal of Marketing Research, 17, 423-431.

Teller, C. (2008). Shopping streets versus shopping malls - determinants of agglomeration format attractiveness from the consumers' point of view. International Review of Retail, Distribution and Consumer Research, 18, 381-403.

Teller C., \& Elms, J. R. (2009). Managing the attractiveness of evolved and created retail agglomeration formats. Marketing Intelligence \& Planning, 28, 25-45.

Teller, C., \& Elms, J. R. (2010). Urban place marketing and retail agglomeration customers. Journal of Marketing Management, in print, DOI: 10.1080/0267257X.2010.517710.

Teller, C., \& Reutterer, T. (2008). The evolving concept of retail attractiveness: What makes retail agglomerations attractive when customers shop at them? Journal of Retailing and Consumer Services, 15, 127-143. 
Teller, C., Reutterer, T., \& Schnedlitz, P. (2008). Hedonic and utilitarian shopper types in evolved and created retail agglomerations. International Review of Retail, Distribution and Consumer Research, 18, 283-309.

Turley L. W., \& Chebat J. C. (2002). Linking retail strategy, atmospheric design and shopping behaviour. Journal of Marketing Management, 18, 125-144.

Turley, L. W., \& Milliman, R. E. (2000). Atmospheric effects on shopping behavior: a review of the experimental evidence. Journal of Business Research, 49, 193-211.

Van Kenhove, P., de Wulf, K., \& van Waterschoot, W. (1999). The impact of task definition on store-attribute saliences and store choice. Journal of Retailing, 75, 125-137.

Ward, P., Davies, B. J., \& Kooijman, D. (2003). Ambient smell and the retail environment: relating olfaction research to consumer behaviour. Journal of Business and Management, 9, 289-302. 


\section{Appendix}

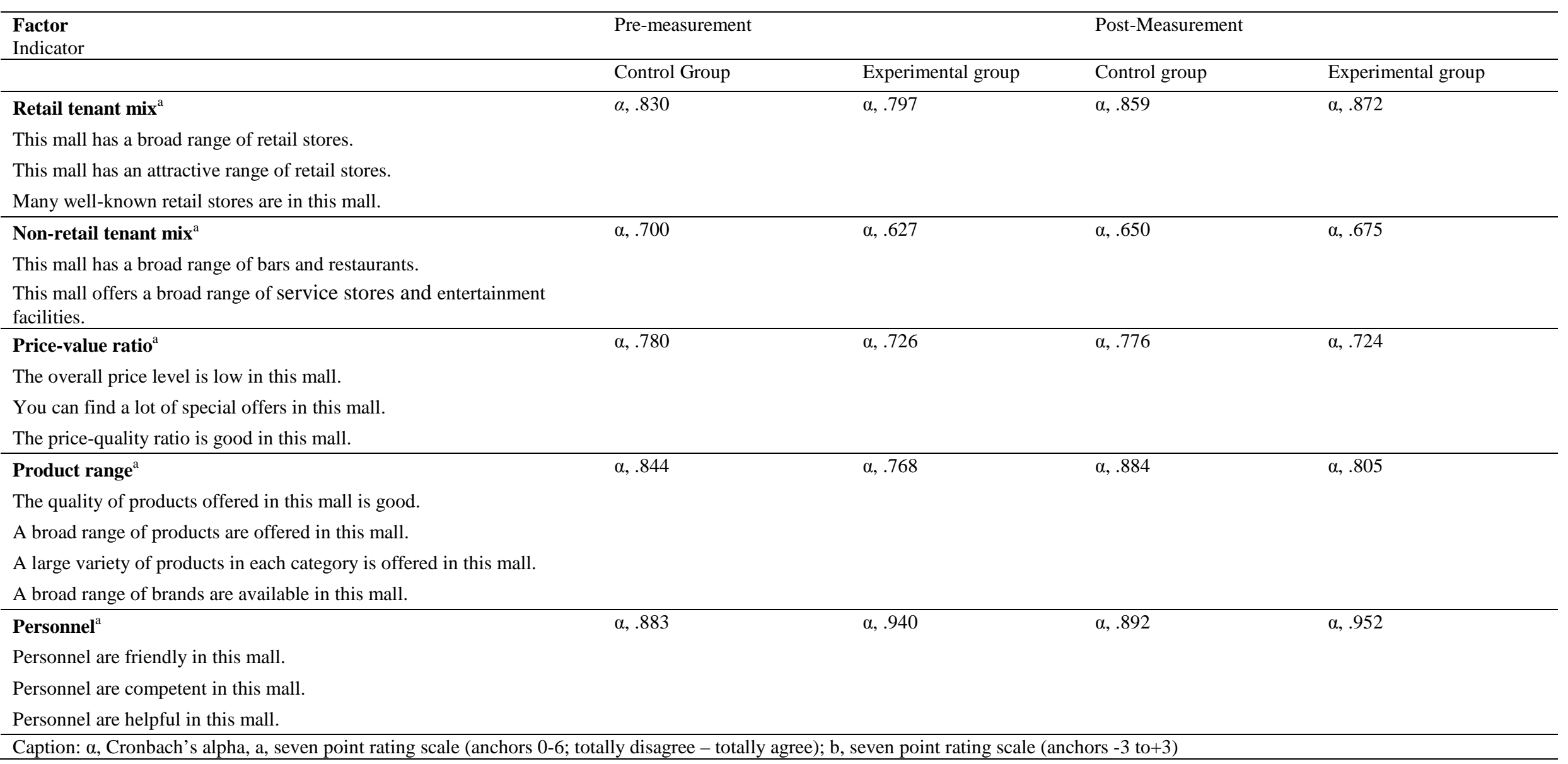




\section{Appendix (continued)}

\begin{tabular}{|c|c|c|c|c|}
\hline \multirow{2}{*}{$\begin{array}{l}\text { Factor } \\
\text { Indicator }\end{array}$} & \multicolumn{2}{|l|}{ Pre-measurement } & \multicolumn{2}{|c|}{ Post-Measurement } \\
\hline & Control Group & Experimental group & Control group & Experimental group \\
\hline Atmospheric stimuli $^{\text {a }}$ & $\alpha, .819$ & $\alpha, .843$ & $\alpha, .840$ & $\alpha, .864$ \\
\hline \multicolumn{5}{|c|}{ The architecture of this mall is appealing. } \\
\hline \multicolumn{5}{|c|}{ It smells pleasantly in this mall. } \\
\hline \multicolumn{5}{|c|}{ The air is pleasant in this mall. } \\
\hline \multicolumn{5}{|c|}{ The temperature is pleasant in this mall. } \\
\hline \multicolumn{5}{|c|}{ It is pleasantly bright in this mall. } \\
\hline \multicolumn{5}{|c|}{ The colour-design of this mall is likable. } \\
\hline \multicolumn{5}{|l|}{ This mall is always clean. } \\
\hline \multicolumn{5}{|c|}{ There is a good mood in this mall } \\
\hline \multicolumn{5}{|c|}{ There is a pleasant atmosphere in this mall. } \\
\hline Pleasure $^{\mathrm{b}}$ & $\alpha, .816$ & $\alpha, .843$ & $\alpha, .852$ & $\alpha, .918$ \\
\hline \multicolumn{5}{|l|}{ Unhappy-happy } \\
\hline \multicolumn{5}{|l|}{ Annoyed-pleasant } \\
\hline \multicolumn{5}{|l|}{ Unsatisfied-satisfied } \\
\hline \multicolumn{5}{|l|}{ Melancholic/contented } \\
\hline Arousal $^{\mathrm{b}}$ & $\alpha, .634$ & $\alpha, .642$ & $\alpha, .610$ & $\alpha, .683$ \\
\hline \multicolumn{5}{|l|}{ Relaxed-stimulated } \\
\hline Calm-excited & & & & \\
\hline
\end{tabular}

Caption: $\alpha$, Cronbach's alpha, a, seven point rating scale (anchors $0-6$; totally disagree - totally agree); $b$, seven point rating scale (anchors -3 to +3 ) 